\title{
SYNTHESIS AND ANTICONVULSANT ACTIVITY EVALUATION OF N-[(2,4-DICHLOROPHENYL)METHYL]-2-(2,4-DIOXO-1H-QUINAZOLIN-3- YL)ACETAMIDE NOVEL 1-BENZYLSUBSTITUTED DERIVATIVES
}

\author{
Wassim El Kayal, Hanna Severina, Vadim Tsyvunin, Sergiy Zalevskyi, Sergiy Shtrygol, \\ Sergiy Vlasov, Olga Golovchenko, Sergiy Kovalenko, Victoriya Georgiyants
}

\begin{abstract}
The aim. Synthesis of 1-benzylsubstituted derivatives of N-[(2,4-dichlorophenyl)methyl]-2-(2,4-dioxo-1h-quinazolin-3yl)acetamide, and determination of affinity to GABAergic biotargets with the following anticonvulsant activity estimation using PTZ-induced seizures model in mice.

Materials and methods. Standard organic synthesis methods were used; the structure of the synthesized compounds was proved by elemental analysis, ${ }^{1} H$ and ${ }^{13} C N M R$ spectroscopy, and LC/MS method; composition of the synthesized compounds - by elemental analysis, their individuality - by TLC and LC/MS methods. AutoDockTools-1.5.6, as well as AutoDock Vina software, was used to perform molecular docking. Anticonvulsant activity was studied using pentylenetetrazole-induced seizures in mice.
\end{abstract}

Results. A targeted N-[(2,4-dichlorophenyl)methyl]-2-(1-(R-benzyl)-2,4-dioxo-quinazolin-3-yl)acetamides were obtained by alkylation of $N$-[(2,4-dichlorophenyl)methyl]-2-(2,4-dioxo-1H-quinazolin-3-yl)acetamide by corresponding 1-chloromethylbenzene in dimethylformamide environment with excess of potassium carbonate at a temperature 70-80 ${ }^{\circ} \mathrm{C}$. Prediction of activity of 1-benzyl derivatives in the pentylenetetrazole-induced seizures in an in vivo experiment was carried out according to the obtained results of docking studies - affinity calculation for GABA receptor and GABA enzyme active sites, as well as analysis of conformational placement in them. In relation to the binding energy, the studied ligands were inferior to the reference drugs: GABA receptor positive allosteric modulators - benzamidine and diazepam, and GABA inhibitor - vigabatrin. The synthesized substances did not show anticonvulsant activity: only 2 compounds have shown a tendency to their activity manifestation according to the criterion of integral protective indicator - reduction of mortality by $17 \%$ compared to control, as well as prolonging the time death of the animals. Comparison with the preliminary obtained results of the activity of the promising anticonvulsant $N-[(2,4-$ dichlorophenyl)methyl] -2-(2,4-dioxo-1H-quinazolin-3-yl) acetamide N-[(2,4-dichlorophenyl)methyl]-2-(2,4-dioxo-1Hquinazolin-3-yl)acetamide made possible to prove the pharmacophore role of the cyclic amide fragment in anticonvulsant activity manifestation.

Conclusion. The synthesis of N-[(2,4-dichlorophenyl)methyl]-2-(1-(R-benzyl)-2,4-dioxo-quinazolin-3-yl)acetamides, which have not still described in the literature, was carried out, as well as the structure of the mentioned compounds was proved. Unfortunately, the substances did not show anticonvulsant activity on the model of pentylenetetrazoleinduced seizures. However, the obtained results allowed establishing the key role of the NHCO cyclic fragment on anticonvulsant activity. A positive correlation between the results of in vivo studies and in silico calculations was foundthe model of pentylenetetrazole-induced seizures and docking into the active sites of PAMs $G A B A_{A}$ receptor and enzyme inhibitor $G A B A_{A T}$, which allows to recommend the given docking methodology as a tool to streamline and optimize the screening on the mentioned model

Keywords: synthesis, quinazolin, benzyl, docking, GABA, anticonvulsant activity anticonvulsant activity anticonvulsant activity

How to cite:

El Kayal, W., Severina, H., Tsyvunin, V., Zalevskyi, S., Shtrygol, S., Sharkh, A. A., Vlasov, S., Golovchenko, O., Kovalenko, S., Georgiyants, V. (2022). Synthesis and anticonvulsant activity evaluation of $\mathrm{n}$-[(2,4-dichlorophenyl)methyl]-2-(2,4-dioxo-1h-quinazolin-3-yl)acetamide novel 1benzylsubstituted derivatives. ScienceRise: Pharmaceutical Science, 1 (35), 58-69. doi: http://doi.org/10.15587/1729-4061.2022.253554

(C) The Author(s) 2022

This is an open access article under the Creative Commons CC BY license hydrate

\section{Introduction}

Epilepsy is a neurological disease characterized by a persistent predisposition to epileptic seizures and related cognitive, psychological, and social consequences [1]. Epilepsy remains one of the most widespread neurological diseases [2], affecting about $1 \%$ of the total pop- ulation of all ages [3] and leading to the patients' disability. According to the statistical data, several comorbid conditions are observed in patients with epilepsy, and the main part belongs to neurological and mental disorders, including neuropathic pain, migraine, depression, anxiety, psychosis, neurosis, dementia, etc. $[4,5]$. 
In modern neurological practice, about 30 anticonvulsants of three generations are used [6], and almost the same number is in preclinical and clinical trials [3]. In recent decades, such a dynamic search for new antiepileptic drugs (AEDs) is due both to the severe side effects of the existing ones [7, 8], and to increasing rates of refractory epilepsy forms development. About 20-30\% of patients have the lack of sensitivity to pharmacocorrection, even with combination therapy including 2-3 anticonvulsants [9, 10]. It should also be noted, that the discovery of new anticonvulsant biotargets, aspects of epileptogenesis development and vectors for its modulation stipulate the need of the further search for new substances having multifactorial mechanisms of anticonvulsant activity realization, better efficiency and higher safety profile.

Structural modification of the known drugs is a component of the modern rational drug-design of anticonvulsants [11]. Metaqualone is of considerable interest in this direction due to it's a positive allosteric modulator of the GABA receptor with pronounced anticonvulsant, hypnotic and soporific activity [12].

In result of its structure modification, anticovulsants having a spectrum of activity in models of chemotoxic convulsions and maximal electroshock seizures (MES) were obtained (Fig. 1) [13, 14], but none of them is currently used due to its ability to become addictive.<smiles>Cc1ccccc1-n1c(C)nc2ccccc2c1=O</smiles>

Methaqualone<smiles>Cc1nc2ccccc2c(=O)n1-c1ccccc1Cl</smiles>

Mecloqualone<smiles>Cc1ccccc1-n1c(CF)nc2ccc(N)cc2c1=O</smiles>

Afaqualone<smiles>O=C(Cn1c(=O)[nH]c2ccccc2c1=O)NCc1ccc(Cl)cc1Cl</smiles>

Promising anticonvulsant

Fig. 1. Methaqualone and its structural analogues with anticonvulsant activity

$\mathrm{N}-[(2,4-$ dichlorophenyl)methyl]-2-(1-(R-benzyl)2,4-dioxo-quinazolin-3-yl)acetamides was synthesized as a structural metaqualone analogue in result of our own research (Fig. 1), and its strong anticonvulsant potential in the model of pentylenetetrazole induced (PTZ) seizures in mice was detected [15]. It was found that the studied compound completely protects the laboratory animals from seizures and mortality and exceeds the reference drug sodium valproate.

The quinazoline 1 derivative has shown low toxicity and no muscle relaxant effect on the laboratory animals in the rotarod test, but it also has shown slight activity on the model of MES. Based on the principles of the pharmacophore model of AEDs development [16], the study was continued to modify the structure of the leader compound in the previous research [15] to possibly improve the pharmacological profile.

The aim of research. The aim of the given study was the synthesis of 1-benzyl-substituted derivatives of $\mathrm{N}$-[(2,4-dichlorophenyl)methyl]-2-(1-(R-benzyl)-2,4dioxo-quinazolin-3-yl)acetamide, determination of affinity for GABAergic biotargets with the following study of their anticonvulsant activity using the model of PTZ induced seizures in mice.

\section{Planning (methodology) of research}

The study is based on the modification of «quinazoline» matrix - the main structural fragment of the anticonvulsant metaqualone and includes all stages of the «drug-design» modern concept (Fig. 2).

In designing the target compounds, the principles of the pharmacophore model of AEDs creation were kept [16], and logical-structural analysis of the literature data concern the fragmentary effect on the level of anticonvulsant activity was followed. The pharmacophoresis of the cyclic $\mathrm{NHC}=\mathrm{O}$ group as a hydrogen bonds domain for possible stabilization of the ligand conformation in the active site of the receptor has been repeatedly discussed $[17,18]$. On the other hand, introduction of distally allocated hydrophobic domains increases lipophilicity, strength and duration of activity. In the modern AEDs: lacosamide, retigabine and rufinamide, the role of the hydrophobic domain is performed by the benzyl substituent [16]. According to the literature data, in the structure of quinazolinone derivatives, benzyl radical also increased the anticonvulsant activity level $[19,20]$. Therefore, for potential improvement of the activity parameters of the leader compound of the previous studies and determination of the role of the cyclic amide fragment of derivative 1 on the anticonvulsant activity manifestation, its Nbenzyl-substituted derivatives were constructed (Fig. 3). 

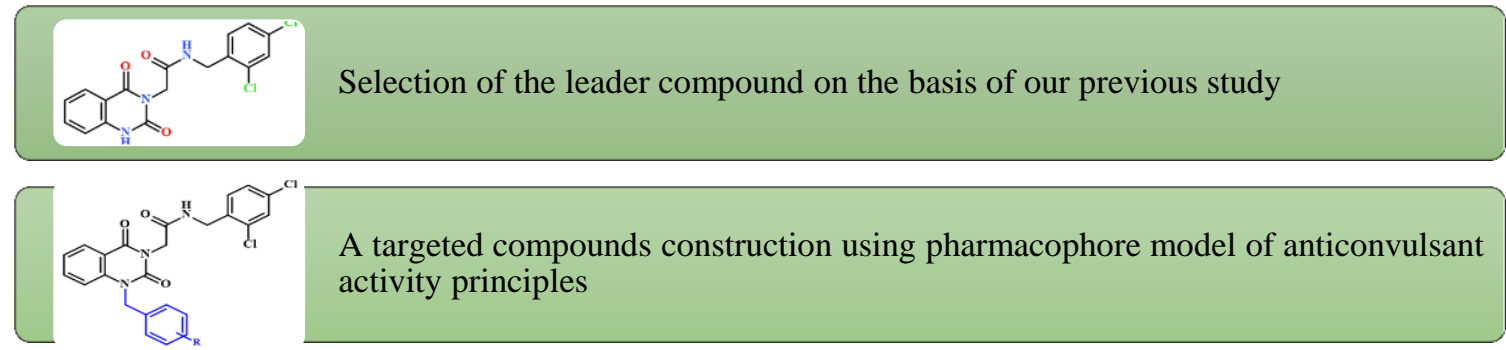

Synthesis of compounds and their structure substantiation

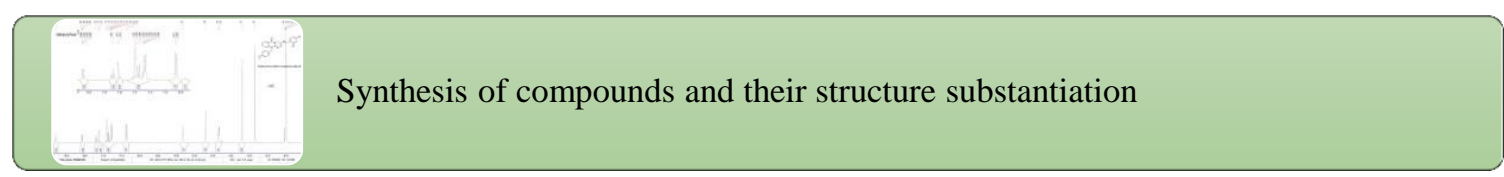

Estimation of the affinity of the studied ligands to GABAergic biotargets using molecular docking tools, and the choice of compounds for in vivo studies

PTZ Pharmacological screening using the model of PTZ induced seizures

Fig. 2. Algorithm of the research

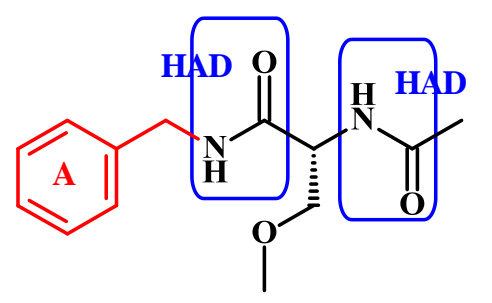

Lacosamide

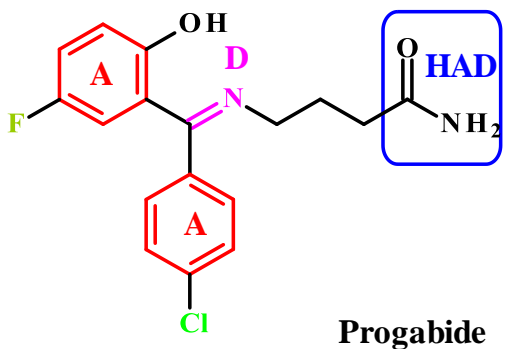<smiles>NC(=O)c1cnn(Cc2c(F)cccc2F)n1</smiles>

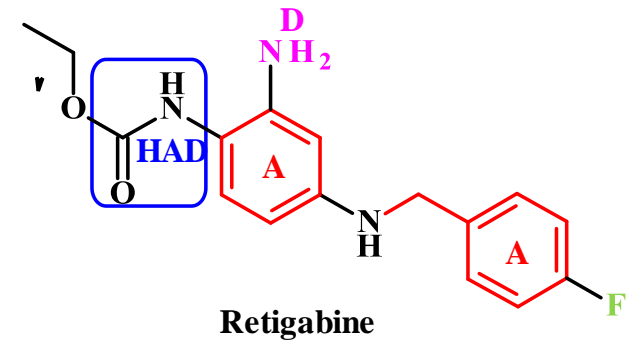

Retigabine

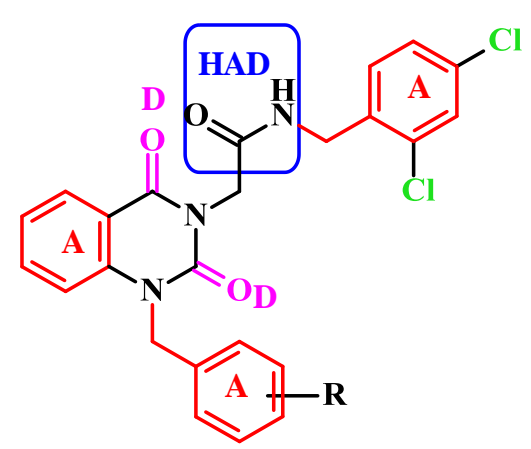

Target substances

\section{Rufinamide}

$\mathrm{A}=$ hydrofobic domen $\quad \mathrm{HAD}=$ hydrogen bond domen - acceptor/donor $\quad \mathrm{D}=$ electron donor

Fig. 3. Pharmacophore model principles of anticonvulsant activity on example of the modern AEDs and the targeted compounds

The choice of radicals in the aryl fragment was based on the literature data and our research results con- cerning the substituents effect on anticonvulsant activity $[21,22]$. Introduction of fluorobenzyl radicals was due to 
the presence of fluoroaryl radicals in the structure of the modern anticonvulsants retigabine, rufinamide, progabide (Fig. 1).

The search for new AEDs in accordance with the International League Against Epilepsy (ILAE) and the Epilepsy Therapy Screening Program (ETSP) recommendations [23] consisted of the integrated use of the screening models of seizures having various pathogenesis. However, high mortality rates of the animals during a pharmacological experiment interfere with effective search for AEDs and require substantiation of its expediency. The use of the modern target-oriented virtual screening was planned to rationalize the search for new AEDs by predicting their activity on the screening model.

\section{Materials and methods}

Sigma-Aldrich (USA) solvents and reagents were used in the study. TLC method with «SorbfilUV-254» plates was used to control the reactions. Chromatography eluent - ethyl acetate - methanol system (9:1), iodine vapor was used as developer. Melting temperatures $\left({ }^{\circ} \mathrm{C}\right)$ were determined in the capillary on the electrothermal digital device IA9100X1 (Bibby Scientific Limited, Staffordshire, UK). Euro Vector EA-3000 (Eurovector SPA, Redavalle, Italy) micro analyzer was used for elemental analysis. The obtained elemental analysis results were within $\pm 0.4 \%$ of the theoretical values. ${ }^{1} \mathrm{H}$ and ${ }^{13} \mathrm{C}$ spectra of the synthesized compounds were obtained using Bruker Varian Mercury (Varian Inc., Palo Alto, CA, USA), $400 \mathrm{MHz}$ and $100 \mathrm{MHz}$ frequency, respectively, DMSO-d6 was used as a solvent, internal standard tetramethylsilane. Chemical shifts are given in the scale $\delta$ ppm. LC/MS spectra were registered by liquid chromatography AP ESCIEXAPI 150E X detector.

N-[(2,4-dichlorophenyl)methyl]-2-(2,4-dioxo-

1H-quinazolin-3-yl)acetamide (1) was obtained and described previously [15].

General method of N-[(2,4-dichlorophenyl) methyl]-2-(1-(R-benzyl)-2,4-dioxo-quinazolin-3-yl)acetamide 3.1-3.11 synthesis

A mixture of $\mathrm{N}$-[(2,4-dichlorophenyl)methyl]-2(2,4-dioxo-1H-quinazolin-3-yl)acetamide $(0.2 \mathrm{~g}, \quad 0.53$ $\mathrm{mmol})$ and dry potassium carbonate $(0.22 \mathrm{~g}, 1.59 \mathrm{mmol})$ were dissolved in $2 \mathrm{ml}$ of dry DMFA and mixed during 15 minutes at a room temperature. Then the alkylator the corresponding substituted benzyl chloride $(0.58 \mathrm{mmol})$ - was added into the reaction mixture, and it was stirred at $80^{\circ} \mathrm{C}$ for $8-10$ hours. The reaction was monitored by TLC in ethyl acetate - methanol system (9:1). As soon as the reaction completed, the solution was diluted with water $(25-50 \mathrm{ml})$. The resulting precipitate was filtered off and washed with water $(20 \mathrm{ml})$. The substance was crystallized from methanol. Product yield was $80-95 \%$.

\subsection{Molecular docking}

AutoDock Vina ta AutoDockTools 1.5.6 software was used for molecular docking studies [24]. Protein Data Bank macro molecules were used as biotargets [25]: $\mathrm{GABA}_{\mathrm{A}}$ (PDB ID 4COF and 6HUP), GABA $\mathrm{AT}$ (PDB ID-10HW).

BIOVIADraw 2017R2 tool was used to construct the database of candidate structures, which were saved as .mol files. The structures were optimized by Chem3D software using MM2 molecular mechanical algorithm and saved as .pdb files. Then, they were converted to .pdbqt by AutoDockTools-1.5.6 [26]. Discovery Studio Visualizer 2017/R2 was used to remove the solvent and native ligand from the macromolecule, the latter was saved in .pdb format. Polar hydrogen atoms were added to the protein structure and saved in .pdbqt format using AutoDockTools-1.5.6.

Grid box size and its center was indicated by the native ligand.

$\mathrm{GABA}_{\mathrm{A}}(\mathrm{PDB}$ ID 4COF): $\mathrm{x}=-3.45, \mathrm{y}=-31.27$, $\mathrm{z}=118$; size $\mathrm{x}=30, \mathrm{y}=32, \mathrm{z}=84$;

GABA $_{A}$ (PDB ID 6HUP): $x=117.4, y=157.4$, $\mathrm{z}=110,4$; size $\mathrm{x}=26, \mathrm{y}=28, \mathrm{z}=20$;

$\mathrm{GABA}_{\mathrm{AT}}$ (PDB ID 10HW): $\mathrm{x}=9.75, \mathrm{y}=-0.87$, $z=20.85$; size $x=28, y=24, z=28$.

Discovery Studio V17.2.0.16349 was used for visualization and analysis of the obtained docking results.

\subsection{Anticonvulsant activity}

Animals

Random-bred male albino mice with an average weight $18-22 \mathrm{~g}$ were purchased from the Animal House of the Central Research Laboratory of the Educational and Scientific Institute of Applied Pharmacy of the National University of Pharmacy, (Kharkiv, Ukraine) for pharmacological study. Every group of 10 animals was kept in standard plastic cages, at room temperature of $20 \pm 2 \circ \mathrm{C}$, exposed to a $12: 12 \mathrm{~h}$ light/dark cycle, with a standard laboratory feeding and drinking regimen.

All types of pharmacological studies started at 9 a.m. and finished before 3 p.m. The purchased laboratory mice were randomly divided in tested groups consisting of 6 animals. All the necessary procedures involving animals were performed in accordance with the ethical standards of the institution or practice, responsible for the studies and were approved by the Local Ethical Committee in National University of Pharmacy, Kharkiv, Ukraine (Approval No: 3/2019). The studies met the requirements of Directive 2010/63/EU of the European Parliament and of the Council of 22 September 2010 on the Protection of Animals Used for Scientific Purposes, the procedures and requirements of The State Expert Center of the Ministry of Health of the Ukraine, the rules of The European Convention for the Protection of Vertebrate Animals used for Experimental and Other Scientific Purposes (Strasbourg, 1986), the resolution of the First National Congress on Bioethics (Kyiv, 2001), and the Law of Ukraine №3447- IV «On Protection of Animals from Cruel Treatment» dated 02.21.2006.

Subcutaneous Pentylenetetrazole Model (scPTZ) [27]

The mice were divided into groups: the $1^{\text {st }}$ group is the control $(n=6)$ - the model of corazole-induced seizures (Pentylenetetrazole, «Sigma», USA) in the dose of $90 \mathrm{mg} / \mathrm{kg}$ subcutaneously as a water solution; the $2^{\text {nd }}$ reference drug group $(n=6)-$ sodium valproate ( $(\mathrm{DDe}$ pakine», Sanofi-Aventis, France) in the dose of $300 \mathrm{mg} / \mathrm{kg}$ [28] intragastrically 30 minutes before cora- 
zole administration. The $3^{\text {rd }}-6^{\text {th }}$ groups are the tested animals $(n=6)$ having the studied compounds in empirical doses of $100 \mathrm{mg} / \mathrm{kg}$ through a tube into the stomach as a suspension in twin-80 30 minutes before PTZ injection.

The effect of the compounds was estimated by the latent period of clonic or tonic seizures, the number of clonic-tonic paroxysms per mouse, the number of animals with clonic and tonic seizures, the severity of seizures, duration of the seizure period, time of death and lethality. If seizures did not occur within 1 hour, the latency period was taken for 60 minutes. The severity of seizures was determined in points: 1 - tremor, 2 - manege running, 3 - clonic seizures, 4 - clonic-tonic convulsions with lateral position, 5 - tonic extension, $6-$ tonic extension, which leads to the death of animals.

\subsection{Statistical analysis}

STATISTICA 12.0 for Windows was used for statistical analysis. The obtained data were reported as the mean \pm standard error of mean (mean \pm SEM). The statistical significance level was considered as $p<0.05$. The parametric Student's t-test (normal distribution) and nonparametric Mann-Whitney U-tests (distribution absence) were used to analyze the statistical differences between the groups. The Fisher's angular transformation (with Yates's correction, if necessary) was used to explain the alternative results (lethality, percentage of mice with clonic and tonic convulsions).

\section{Result}

The initial N-[(2,4-dichlorophenyl)methyl]-2-(2,4dioxo-1H-quinazolin-3-yl)acetamide (1) ) synthesized according to the previously developed preparative method [15]: from methyl 2-isothiocyanatobenzoate and glycine, obtained 2- (4-oxo-2-thioxo-1,4-dihydroquinazolin-3(2H)yl)acetic acid, converted to 2-(2,4-dioxo-1,4-dihydroquinazolin-3 $(2 H)$-yl)acetic acid by hydrogen peroxide oxidation, the interaction of the latter with $\mathrm{N}, \mathrm{N}^{\prime}$ carbonyldiimidazole and 2-chloro-N-[(2,4- dichlorophenyl)methyl]acetamide allowed to obtain the target acetamide 1 (Fig. 4)

Alkylation of $\mathrm{N}-[(2,4-$ dichlorophenyl) methyl]-2(2,4-dioxo-1H-quinazolin-3-yl) acetamide (1) was carried out by interaction with the corresponding 1chloromethylbenzene (2) in dimethylformamide medium in the presence of potassium carbonate excess at a temperature of $7080{ }^{\circ} \mathrm{C}$, i.e. under traditional alkylation conditions $[18,29]$.

The synthesized compounds 3.1-3.11 are white crystalline substances having exact values of melting points (Table 1). All 3.1-3.11 derivatives are easily soluble in dioxane, dimethylformamide, and insoluble in water. The structure of the synthesized compounds and their individuality were proved by TLC, LC/MS, ${ }^{1} \mathrm{H}$ NMR spectroscopy, and elemental analysis. For 3.1, 3.7, and 3.10 compounds, the structure was additionally proved by ${ }^{13} \mathrm{C}$ NMR spectroscopy data.<smiles>[R]c1ccc(CCl)cc1</smiles><smiles>[R]c1ccc(Cn2c(=O)n(CC(=O)NCc3ccc(Cl)cc3Cl)c(=O)c3ccccc32)cc1</smiles>

\section{R= 3.1 3-Cl; 3.2 4-Cl; 3.3 2,4-diMe; 3.4 2,5-diMe; 3.5 2-F; 3.6 2,4-diF; 3.7 2-CN; 3.8 4-NO ${ }_{2}$; 3.9 4-OMe; 3.10 3-F, 4-OMe; 3.11 2-Cl, 4-F}

Fig. 4. The synthesis of N-[(2,4-dichlorophenyl)methyl]-2-(1-(R-benzyl)-2,4-dioxo-quinazolin-3-yl)acetamide

All corresponding proton signals were present in the ${ }^{1} \mathrm{H}$ NMR spectra (Table 2). When compared with the spectrum of the original acetamide 1 [15], the appearance of benzyl radical protons - methylene group signal in singular form at 5.55-5.25 ppm, as well as additional aromatic protons appearance, and the absent signal of NHCO group of quinazoline cycle at $11.5 \mathrm{ppm}$ were specific for the spectra of all synthesized compounds 3.1-3.11. The large number of aromatic protons in the structure of 3.1-3.11 compounds led to their signals overlaying, which complicated their interpretation with reference to the allocation in the cycle, but their number was fully consistent with the structure of compounds. The proton signal of the NHCO benzylamide residue group resonated in the triplet form at $\delta 8.82-9.72 \mathrm{ppm}$, and the methylene group - in the doublet form at 4.35-4.33 ppm. Protons of the methylene $\mathrm{CH}_{2} \mathrm{CO}$ group of 3.1-3.11 compounds were detected as singles in 4.71-4.68 ppm range. Signals of methoxy and methyl groups in 3.3, 3.4 and 3.9, 3.10 compounds, respectively, were also recorded. 
Table 1

Physico-chemical characteristics of N-[(2,4-dichlorophenyl)methyl]-2-(1-(R-benzyl)-2,4-dioxo-quinazolin-3yl)acetamide (3.1-3.9)

\begin{tabular}{|c|c|c|c|c|c|c|c|c|c|}
\hline \multirow{2}{*}{$\begin{array}{l}\text { № } \\
\text { i/o }\end{array}$} & \multirow[t]{2}{*}{$\mathrm{R}$} & \multirow{2}{*}{$\begin{array}{l}\text { Yield } \\
\%\end{array}$} & \multirow{2}{*}{ Melting temp. } & \multirow[t]{2}{*}{ Gross formula } & \multirow[t]{2}{*}{$\mathrm{Mm}$} & \multicolumn{3}{|c|}{$\frac{\text { Calculated, } \%}{\text { Found, } \%}$} & \multirow{2}{*}{$\begin{array}{c}\mathrm{LC} / \mathrm{MS} \mathrm{m} / \mathrm{z} \\
{[\mathrm{M}+\mathrm{H}]}\end{array}$} \\
\hline & & & & & & $\mathrm{C}$ & $\mathrm{H}$ & $\mathrm{N}$ & \\
\hline 3.1 & $3-\mathrm{Cl}$ & 90 & $233-5$ & $\mathrm{C}_{24} \mathrm{H}_{18} \mathrm{Cl}_{3} \mathrm{~N}_{3} \mathrm{O}_{3}$ & 502.78 & $\frac{57.33}{57.30}$ & $\frac{3.61}{3.58}$ & $\underline{8.36}$ & 504.0 \\
\hline 3.2 & 4-Cl & 95 & $235-7$ & $\mathrm{C}_{24} \mathrm{H}_{18} \mathrm{Cl}_{3} \mathrm{~N}_{3} \mathrm{O}_{3}$ & 502.78 & $\frac{57.33}{57.29}$ & $\frac{3.61}{3.59}$ & $\frac{8.36}{8.39}$ & - \\
\hline 3.3 & 2,4-diMe & 83 & $228-30$ & $\mathrm{C}_{26} \mathrm{H}_{23} \mathrm{Cl}_{2} \mathrm{~N}_{3} \mathrm{O}_{3}$ & 496.38 & $\frac{62.91}{62.84}$ & $\frac{4.67}{4.64}$ & $\frac{8.47}{8.50}$ & 497.3 \\
\hline 3.4 & 2,5-diMe & 80 & $222-6$ & $\mathrm{C}_{26} \mathrm{H}_{23} \mathrm{Cl}_{2} \mathrm{~N}_{3} \mathrm{O}_{3}$ & 496.38 & $\frac{62.91}{62.85}$ & $\frac{4.67}{4.65}$ & $\frac{8.47}{8.49}$ & 496.9 \\
\hline 3.5 & $2-\mathrm{F}$ & 86 & $210-2$ & $\mathrm{C}_{24} \mathrm{H}_{18} \mathrm{Cl}_{2} \mathrm{FN}_{3} \mathrm{O}_{3}$ & 486.32 & $\frac{59.27}{59.22}$ & $\frac{3.73}{3.70}$ & $\frac{8.64}{8.66}$ & 487.1 \\
\hline 3.6 & 2,4-diF & 82 & $165-7$ & $\mathrm{C}_{24} \mathrm{H}_{17} \mathrm{Cl}_{2} \mathrm{~F}_{2} \mathrm{~N}_{3} \mathrm{O}_{3}$ & 504.31 & $\frac{57.16}{57.12}$ & $\frac{3.40}{3.38}$ & $\frac{8.33}{8.36}$ & 505.1 \\
\hline 3.7 & $2-\mathrm{CN}$ & 88 & $230-2$ & $\mathrm{C}_{25} \mathrm{H}_{18} \mathrm{Cl}_{2} \mathrm{~N}_{4} \mathrm{O}_{3}$ & 493.34 & $\frac{60.86}{60.83}$ & $\frac{3.68}{3.65}$ & $\frac{11.36}{11.39}$ & 493.4 \\
\hline 3.8 & $4-\mathrm{NO}_{2}$ & 80 & $288-90$ & $\mathrm{C}_{24} \mathrm{H}_{18} \mathrm{Cl}_{2} \mathrm{~N}_{4} \mathrm{O}_{5}$ & 513.32 & $\frac{56.15}{56.10}$ & $\frac{3.53}{3.50}$ & $\frac{10.91}{10.96}$ & 513.0 \\
\hline 3.9 & 4-OMe & 93 & $226-8$ & $\mathrm{C}_{25} \mathrm{H}_{21} \mathrm{Cl}_{2} \mathrm{~N}_{3} \mathrm{O}_{4}$ & 498.35 & $\frac{60.25}{60.21}$ & $\frac{4.25}{4.22}$ & $\frac{8.43}{8.47}$ & 498.5 \\
\hline 3.10 & $\begin{array}{l}\text { 3-F, 4- } \\
\mathrm{OMe}\end{array}$ & 88 & $217-9$ & $\mathrm{C}_{25} \mathrm{H}_{20} \mathrm{Cl}_{2} \mathrm{FN}_{3} \mathrm{O}_{4}$ & 516.34 & $\frac{58.15}{58.12}$ & $\frac{3.90}{3.86}$ & $\frac{8.14}{8.18}$ & 516.2 \\
\hline 3.11 & $2-\mathrm{Cl}, 4-\mathrm{F}$ & 82 & $232-4$ & $\mathrm{C}_{24} \mathrm{H}_{17} \mathrm{Cl}_{3} \mathrm{FN}_{3} \mathrm{O}_{3}$ & 520.76 & $\frac{55.35}{55.30}$ & $\frac{3.29}{3.25}$ & $\frac{8.07}{8.10}$ & - \\
\hline
\end{tabular}

Table 2

${ }^{1} \mathrm{H}$ NMR spectra of the synthesized 1-benzyl derivatives of N-[(2,4-dichlorophenyl)methyl]-2-(2,4-dioxo-1Hquinazolin-3-yl)acetamide (3.1-3.11)

\begin{tabular}{|c|c|c|c|c|c|c|}
\hline Compound & $\mathrm{NHCO}, \mathrm{t}, 1 \mathrm{H}$ & $\mathrm{Ar}-\mathrm{H}$ & $\mathrm{CH}_{2} \mathrm{Bn} 2 \mathrm{H} \mathrm{c}$ & $\mathrm{CH}_{2} \mathrm{CO}, 2 \mathrm{H} \mathrm{c}$ & $\mathrm{NHCH}_{2} 2 \mathrm{H}, \mathrm{d}$ & Other protons signals \\
\hline 1 & 2 & 3 & 4 & 5 & 6 & 7 \\
\hline $3.1 *$ & $\begin{array}{c}8.77 \\
\mathrm{~J}=5 \mathrm{~Hz}\end{array}$ & $\begin{array}{c}8.10,1 \mathrm{H}, \mathrm{dd}, \mathrm{J}=1.6 \mathrm{~Hz} \\
7.70,1 \mathrm{H}, \mathrm{t}, \mathrm{J}=8 \mathrm{~Hz} \\
7.59,1 \mathrm{H}, \mathrm{s} \\
7.43,1 \mathrm{H}, \mathrm{s} \\
7.37-7.28,7 \mathrm{H}, \mathrm{m}\end{array}$ & 5.41 & 4.69 & $\begin{array}{c}4.35 \\
\mathrm{~J}=6 \mathrm{~Hz} \\
\mathrm{~J}=4 \mathrm{~Hz}\end{array}$ & - \\
\hline 3.2 & $\begin{array}{c}8.75 \\
\mathrm{~J}=4.8 \mathrm{~Hz}\end{array}$ & $\begin{array}{c}8.091 \mathrm{H}, \mathrm{dd}, \mathrm{J}=1.6 \mathrm{~Hz} \\
7.69,1 \mathrm{H}, \mathrm{t}, \mathrm{J}=8 \mathrm{~Hz} \\
7.59,1 \mathrm{H}, \mathrm{s} \\
7.37-7.228 \mathrm{H}, \mathrm{m}\end{array}$ & 5.38 & 4.69 & $\begin{array}{c}4.34 \\
\mathrm{~J}=6 \mathrm{~Hz}\end{array}$ & \\
\hline 3.3 & $\begin{array}{c}8.75 \\
\mathrm{~J}=5 \mathrm{~Hz}\end{array}$ & $\begin{array}{c}8.10,1 \mathrm{H}, \mathrm{dd}, \mathrm{J}=1.6 \mathrm{~Hz} \\
7.71,1 \mathrm{H}, \mathrm{t}, \mathrm{J}=8.8 \mathrm{~Hz} \\
7.60,1 \mathrm{H}, \mathrm{d}, \mathrm{J}=2.4 \mathrm{~Hz} \\
7.36-7.22,3 \mathrm{H}, \mathrm{m} \\
7.10-7.06,2 \mathrm{H}, \mathrm{m} \\
6.95,1 \mathrm{H}, \mathrm{d} \\
6.64 .1 \mathrm{H}, \mathrm{s}\end{array}$ & 5.25 & 4.70 & $\begin{array}{c}4.34 \\
\mathrm{~J}=6 \mathrm{~Hz}\end{array}$ & $\begin{array}{l}2.33,3 \mathrm{H}, \mathrm{c}, \mathrm{CH}_{3} \\
2.09,3 \mathrm{H}, \mathrm{c}, \mathrm{CH}_{3}\end{array}$ \\
\hline 3.4 & $\begin{array}{c}8.75 \\
\mathrm{~J}=5 \mathrm{~Hz}\end{array}$ & $\begin{array}{c}8.11,1 \mathrm{H}, \mathrm{dd}, \mathrm{J}=1.6 \mathrm{~Hz} \\
7.70,1 \mathrm{H}, \mathrm{t}, \mathrm{J}=8.8 \mathrm{~Hz} \\
7.59,1 \mathrm{H}, \mathrm{d}, \mathrm{J}=2.4 \mathrm{~Hz} \\
7.36-7.22,3 \mathrm{H}, \mathrm{m} \\
7.10,1 \mathrm{H}, \mathrm{d}, \mathrm{J}=8 \mathrm{~Hz} \\
7.06,1 \mathrm{H}, \mathrm{d}, \mathrm{J}=8.4 \mathrm{~Hz} \\
6.95,1 \mathrm{H}, \mathrm{d}, \mathrm{J}=8 \mathrm{~Hz} \\
6.64 .1 \mathrm{H}, \mathrm{s}\end{array}$ & 5.25 & 4.70 & $\begin{array}{c}4.34 \\
\mathrm{~J}=4 \mathrm{~Hz}\end{array}$ & $\begin{array}{l}2.33,3 \mathrm{H}, \mathrm{c}, \mathrm{CH}_{3} \\
2.09,3 \mathrm{H}, \mathrm{c}, \mathrm{CH}_{3}\end{array}$ \\
\hline 3.5 & $\begin{array}{c}8.78 \\
\mathrm{~J}=5 \mathrm{~Hz}\end{array}$ & $\begin{array}{c}8.11,1 \mathrm{H}, \mathrm{dd}, \mathrm{J}=1.2 \mathrm{~Hz} \\
7.72,1 \mathrm{H}, \mathrm{t}, \mathrm{J}=8.8 \mathrm{~Hz} \\
7.60,1 \mathrm{H}, \mathrm{s} \\
7.37,1 \mathrm{H}, \mathrm{s} \\
7.34-7.25,5 \mathrm{H}, \mathrm{m} \\
7.12-7.07,2 \mathrm{H}, \mathrm{m} \\
\end{array}$ & 5.41 & 4.68 & $\begin{array}{c}4.33 \\
\mathrm{~J}=6 \mathrm{~Hz}\end{array}$ & - \\
\hline
\end{tabular}


Continuation of the Table 2

\begin{tabular}{|c|c|c|c|c|c|c|}
\hline 1 & 2 & 3 & 4 & 5 & 6 & 7 \\
\hline 3.6 & $\begin{array}{c}8.76 \\
\mathrm{~J}=5 \mathrm{~Hz}\end{array}$ & $\begin{array}{c}\text { 8.11, } 1 \mathrm{H}, \mathrm{d}, \mathrm{J}=1.2 \mathrm{~Hz} \\
7.72,1 \mathrm{H}, \mathrm{t}, \mathrm{J}=8.8 \mathrm{~Hz} \\
7.60,1 \mathrm{H}, \mathrm{s} \\
7.36-7.27,5 \mathrm{H}, \mathrm{m} \\
7.22-7.11,1 \mathrm{H}, \mathrm{m} \\
6.96-7.07,1 \mathrm{H}, \mathrm{t}, \mathrm{J}=1.2 \mathrm{~Hz}\end{array}$ & 5.37 & 4.61 & $\begin{array}{c}4.33 \\
\mathrm{~J}=5.6 \mathrm{~Hz}\end{array}$ & \\
\hline $3.7 *$ & $\begin{array}{c}8.82 \\
\mathrm{~J}=5 \mathrm{~Hz}\end{array}$ & $\begin{array}{c}8.15,1 \mathrm{H}, \mathrm{d}, \mathrm{J}=8.4 \mathrm{~Hz} \\
7.92,1 \mathrm{H}, \mathrm{d}, \mathrm{J}=8.4 \mathrm{~Hz} \\
7.79,1 \mathrm{H}, \mathrm{t}, \mathrm{J}=8.2 \mathrm{~Hz} \\
7.59,2 \mathrm{H}, \mathrm{t}, \mathrm{J}=8 \mathrm{~Hz} \\
7.48,1 \mathrm{H}, \mathrm{t}, \mathrm{J}=8.2 \mathrm{~Hz} \\
7.35,3 \mathrm{H}, \mathrm{t}, \mathrm{J}=8 \mathrm{~Hz} \\
7.29,1 \mathrm{H}, \mathrm{d}, \mathrm{J}=10 \mathrm{~Hz} \\
7.20,1 \mathrm{H}, \mathrm{d}, \mathrm{J}=10 \mathrm{~Hz}\end{array}$ & 5.55 & 4.66 & $\begin{array}{c}4.33 \\
\mathrm{~J}=5.6 \mathrm{~Hz}\end{array}$ & - \\
\hline 3.8 & $\begin{array}{c}8.79 \\
\mathrm{~J}=5 \mathrm{~Hz}\end{array}$ & $\begin{array}{c}8.17,1 \mathrm{H}, \mathrm{d}, \mathrm{J}=8.8 \mathrm{~Hz} \\
8.10,1 \mathrm{H}, \mathrm{d}, \mathrm{J}=8.8 \mathrm{~Hz} \\
7.70,1 \mathrm{H}, \mathrm{t}, \mathrm{J}=8 \mathrm{~Hz} \\
7.59,3 \mathrm{H}, \mathrm{d}, \mathrm{J}=9.2 \mathrm{~Hz} \\
7.35,1 \mathrm{H}, \mathrm{s} \\
7.32-7.21,4 \mathrm{H}, \mathrm{m}\end{array}$ & 5.54 & 4.68 & $\begin{array}{c}4.33 \\
\mathrm{~J}=5.6 \mathrm{~Hz}\end{array}$ & \\
\hline 3.9 & $\begin{array}{c}8.80 \\
\mathrm{~J}=5 \mathrm{~Hz}\end{array}$ & $\begin{array}{c}8.081 \mathrm{H}, \mathrm{dd}, \mathrm{J}=1.2 \mathrm{~Hz} \\
7.69,1 \mathrm{H}, \mathrm{t}, \mathrm{J}=8 \mathrm{~Hz} \\
7.61,1 \mathrm{H}, \mathrm{dd}, \mathrm{J}=1.6 \mathrm{~Hz} \\
7.40-7.25,6 \mathrm{H}, \mathrm{m} \\
6.86,2 \mathrm{H}, \mathrm{d}, \mathrm{J}=8.4 \mathrm{~Hz}\end{array}$ & 5.32 & 4.69 & $\begin{array}{c}4.33 \\
\mathrm{~J}=5.6 \mathrm{~Hz}\end{array}$ & $3.70,3 \mathrm{H}, \mathrm{s}, \mathrm{OCH}_{3}$ \\
\hline $3.10 *$ & $\begin{array}{c}8.79 \\
\mathrm{~J}=5 \mathrm{~Hz}\end{array}$ & $\begin{array}{c}8.08,1 \mathrm{H}, \mathrm{dd}, \mathrm{J}=1.6 \mathrm{~Hz} \\
7.70,1 \mathrm{H}, \mathrm{t}, \mathrm{J}=8.8 \mathrm{~Hz} \\
7.60,1 \mathrm{H}, \mathrm{s} \\
7.36,2 \mathrm{H}, \mathrm{s} \\
7.35-7.29,2 \mathrm{H}, \mathrm{m} \\
7.20,1 \mathrm{H}, \mathrm{d}, \mathrm{J}=8.4 \mathrm{~Hz} \\
7.12-7.01 .2 \mathrm{H}, \mathrm{m} \\
\end{array}$ & 5.32 & 4.69 & $\begin{array}{c}4.33 \\
\mathrm{~J}=5.6 \mathrm{~Hz}\end{array}$ & $3.79,3 \mathrm{H}, \mathrm{s}, \mathrm{OCH}_{3}$ \\
\hline 3.11 & $\begin{array}{c}8.72 \\
\mathrm{~J}=5 \mathrm{~Hz}\end{array}$ & $\begin{array}{c}8.13,1 \mathrm{H}, \mathrm{d}, \mathrm{J}=7.6 \mathrm{~Hz} \\
7.72,1 \mathrm{H}, \mathrm{t}, \mathrm{J}=8 \mathrm{~Hz} \\
7.58-7.50,2 \mathrm{H}, \mathrm{m} \\
7.35-7.30,3 \mathrm{H}, \mathrm{t}, \mathrm{J}=6.8 \mathrm{~Hz} \\
7.13-7.07,3 \mathrm{H}, \mathrm{m}\end{array}$ & 5.36 & 4.68 & $\begin{array}{c}4.33 \\
\mathrm{~J}=5.6 \mathrm{~Hz}\end{array}$ & \\
\hline
\end{tabular}

Note: ${ }^{* 13} \mathrm{C} \mathrm{NMR}(100 \mathrm{MHz}, \mathrm{DMSO}-\mathrm{d} 6)$ :

$3.1167 .17,161.14,150.88,139.57,138.83,135.46,133.43,132.81,132.24,130.43,129.99,128.52,128.24,128.15,127.35,127.27$, $126.52,125.25,123.14,115.37,114.89,45.90,44.02,39.86$.

$3.7167 .03,161.10,157.81,150.69,139.67,139.62,135.70,135.32,133.63,133.44,132.82,132.24,129.99,129.94,128.53,128.30$, $128,17,127.26,126.29,123.39,117.09,115.29,114.65,110.03,45.37,43.94,39.8$.

$3.10167 .15,161.12,157.92,153.09,150.09,146.38,139.56,135.37,132.83,132.24,130,00,129.04,128.96,128.43,127,26$, $123.06,122.98,115.32,114.99,114.67,114.00,56.02,45.45,43.97,39.86$.

In the ${ }^{13} \mathrm{C}$ NMR spectra of compounds 3.1, 3.7, 3.10, the signals of heterocyclic carbon atoms (the $2^{\text {nd }}$ and the $4^{\text {th }}$ quinazoline ring atoms) and amide carbonyl groups $\mathrm{C}=\mathrm{O}$ could be considered to be specific - three clear signals in the range of 167.17-150.88 ppm. Carbon atoms of aromatic fragments resonate resonated in the specific area - 153.09-114.0 ppm and corresponded to the structure of compounds by the number. The aliphatic methylene groups carbon atoms are clearly identified: $\mathrm{CH}_{2} \mathrm{CO}$ - 45.90-45.37 ppm, $\mathrm{CH}_{2} \mathrm{Bn}-44.02-43.94 \mathrm{ppm}$, $\mathrm{CH}_{2} \mathrm{NH}-39.86-39.80 \mathrm{ppm}$. Carbon of the nitrile group of compound 3.7 was fixed at $110.03 \mathrm{ppm}$, and the methoxy group of compound $\mathbf{3 . 1 0}$ - at $56.02 \mathrm{ppm}$.

Candidate compounds for in vivo experiment were selected according to results of the docking into the active site of the positive allosteric modulator (PAM) of $\mathrm{GABA}_{\mathrm{A}}$ receptor (PAM ID 4COF) [30], the active site of benzdiazepines (BDZ) of $\mathrm{GABA}_{\mathrm{A}}$ receptor (PDB ID 6HUP) [31] and the site $\mathrm{GABA}_{\mathrm{AT}}$ enzyme inhibitor (PDB ID 1OHW) [32]. The choice of biotargets was explained by the fact that the synthesized 3.1-3.11 compounds were quinazolinone $\mathbf{1}$ analogues, which showed its activity on PTZ-induced model of seizures. Efficacy in PTZ-induced model of seizures indicates GABAergic anticonvulsant mechanism [33]. PTZ has a proconvulsive effect due to its ability to bind two active sites of the GABA receptor complex [34] - through a picrotoxin site that inhibits the work of $\mathrm{GABA}_{\mathrm{A}}$ receptors by closing the chloride channel and reducing cortical neurons hyperpolarization, as well as and through competitive binding to benzodiazepine.

The ability of the used docking algorithm to reproduce experimental data was confirmed by evaluation of conformation and interactions between amino acid residues of native reference ligands: benzamidine (BA) and diazepam (DZP) - agonists of $\mathrm{GABA}_{\mathrm{A}} \mathrm{R}$ and vigabatrin $(\mathrm{VGN})-\mathrm{GABA}_{\mathrm{AT}}$ inhibitor. The binding energy was quantified by the affinity (Table 3). 3D visualization of the reference and investigated ligands conformation on the example of 4-methoxybenzyl derivative 3.9 is presented in Fig.4-6. 
Table 3

Binding energies of the studied 3.1-3.11 and reference ligands with $\mathrm{GABA}_{\mathrm{A}}$ and $\mathrm{GABA}_{\mathrm{AT}}$ active sites

\begin{tabular}{|c|c|c|c|}
\hline \multirow{2}{*}{ Ligands } & \multicolumn{3}{|c|}{ Targets } \\
\cline { 2 - 4 } & $\begin{array}{c}\text { GABA }_{\mathrm{A}} \mathrm{R} \\
\text { PAM bind- } \\
\text { ing site }\end{array}$ & $\begin{array}{c}\text { GABA } \mathrm{A}_{\mathrm{A}} \mathrm{R} \\
\text { BDZ bind- } \\
\text { ing site }\end{array}$ & $\begin{array}{c}\text { GABA }_{\mathrm{AT}} \\
\text { inhibitor } \\
\text { binding site }\end{array}$ \\
\hline BA & -8.4 & - & - \\
\hline DZP & - & -9.9 & - \\
\hline VGN & - & - & -8.5 \\
\hline 3.1 & -7.0 & -8.5 & -6.4 \\
\hline 3.2 & -6.9 & -8.4 & -6.5 \\
\hline 3.3 & -7.1 & -8.0 & -7.2 \\
\hline 3.4 & -6.8 & -8.1 & -7.4 \\
\hline 3.5 & -7.0 & -8.2 & -7.6 \\
\hline 3.6 & -7.0 & -8.2 & -7.4 \\
\hline 3.7 & -6.8 & -7.8 & -6.4 \\
\hline 3.8 & -6.8 & -7.9 & -6.6 \\
\hline 3.9 & -7.4 & -9.5 & -6.9 \\
\hline 3.10 & -7.2 & -9.1 & -7.4 \\
\hline 3.11 & -7.1 & -9.0 & -7.3 \\
\hline
\end{tabular}

The binding energies of all synthesized ligands 3.1-3.11 were significantly higher than the binding energies of the reference drugs (Table 3 ), which points to a moderate affinity for the studied biotargets. The best values of scoring functions to all biotargets were calcu-

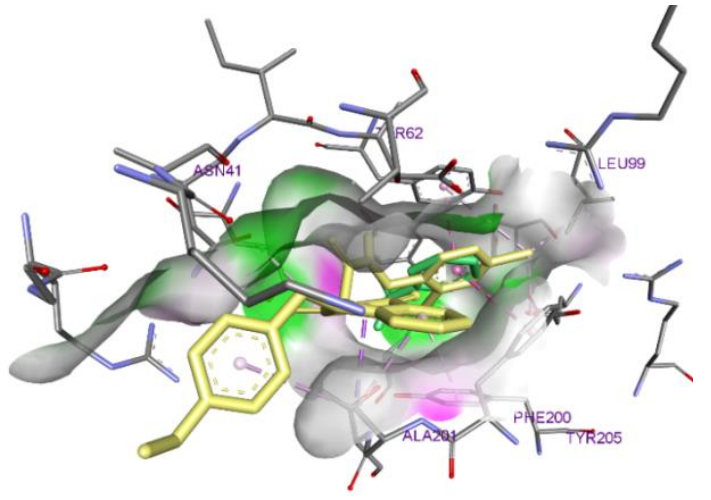

$a$ lated for 4-methoxybenzyl derivative 3.9: -7.4 vs. $-8.4 \mathrm{kcal} / \mathrm{mol}$ in $\mathrm{BA},-9.5 \mathrm{vs}$. $-9.9 \mathrm{kcal} / \mathrm{mol}$ in DZP in the case of $\mathrm{GABA}_{\mathrm{A}},-6.9$ vs. $-8.4 \mathrm{kcal} / \mathrm{mol}$ in $\mathrm{VGN}$ at docking in $\mathrm{GABA}_{\mathrm{AT}}$ enzyme. The worst binding energy was predicted for 4-nitro- (3.8) and 2-cyanobenzylsubstituted (3.7) derivatives.

The conformational arrangement analysis of 3.13.11 ligands into the active site of $\mathrm{GABA}_{\mathrm{A}}$ receptor has shown that immersion into the pocket occurs due to the benzylacetamide fragment (Fig.5a on example of ligand 3.9). The latter starts hydrophobic interaction between tyrosine residues (TYR62, 205) and phenylalanine (PHE200), which are the main for native benzamidine fixation (Fig. 5, b) [30]. Quinazoline pyrimidine fragment also interacted with the active site amino acids, but 1-benzyl radical was fixed outside the pocket, as well as the aromatic ring of quinazoline. According to the virtual prediction results, the stable existence of such a conformation and, accordingly, the possibility of positive allosteric modulation of the $\mathrm{GABA}_{\mathrm{A}}$ receptor by ligands 3.13.11 was improbable.

The highest affinity level of ligands 3.1-3.11 was calculated for the benzdiazepine $\mathrm{GABA}_{\mathrm{A}}$ receptor active site, namely -7.8 to $-9.2 \mathrm{kcal} / \mathrm{mol}$ [31], although inferior to native diazepam affinity $(-9.9 \mathrm{kcal} / \mathrm{mol})$. Conformational allocation in the hydrophobic pocket of the active site is visualized in Fig. 6 a, b on example of $\mathbf{3 . 9}$ derivative

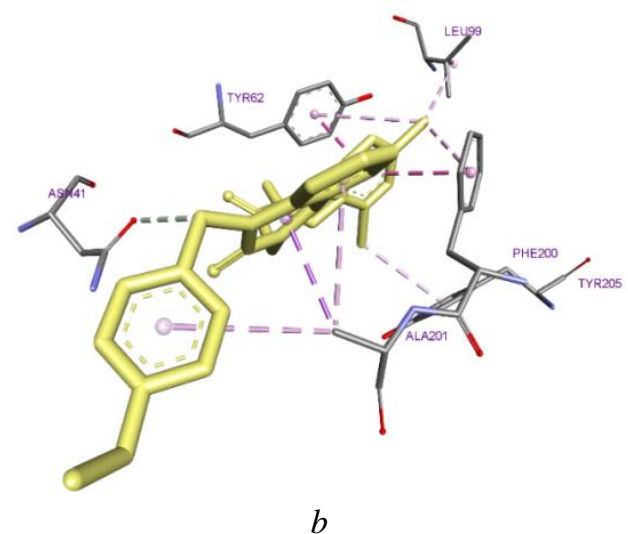

Figure 5. 3D visualization of 3.9 ligand (yellow molecule): $a$ - with BA (green molecule); $b$ - after interrelation with the amino acids of $\mathrm{GABA}_{\mathrm{A}}$ receptor active site

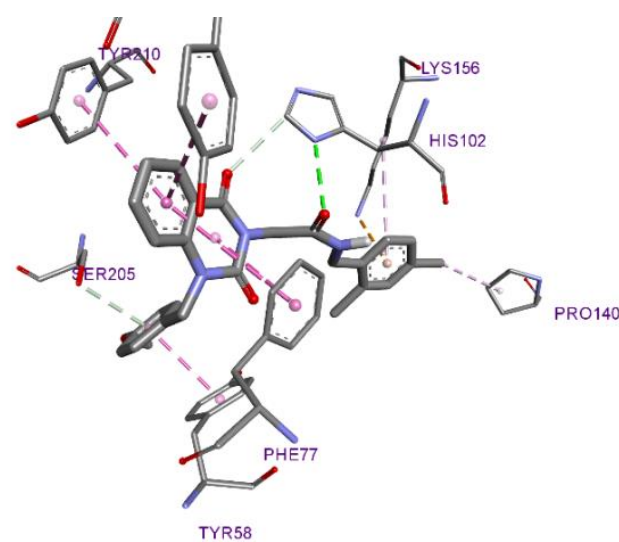

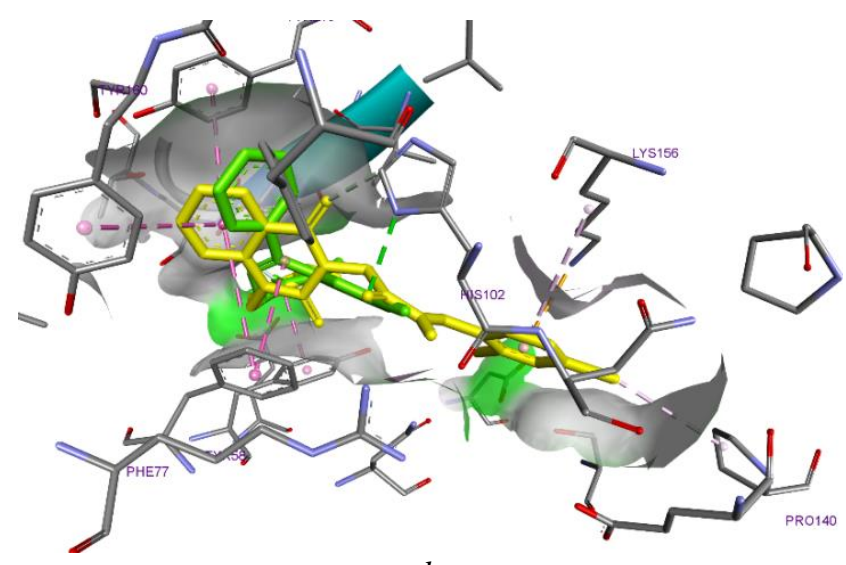

$b$

Fig. 6. $a$-interaction of 3.9 ligand with amino acids in BDZ-site of GABA $\mathrm{A}_{\mathrm{A}}$ receptor; $b$ - compatible conformation of diazepam (green) and 3.9 ligand (yellow) 
Fixation in the active site is due to hydrophobic bonds with the main amino acid residues that interact with diazepam in the experiment: the quinazoline cycle was fixed by hydrophobic interaction with tyrosine TYR210 (stacking interaction), TYR160 and phenylalanine; 2,4-dichlorobenzylacetamide fragment - with proline and histidine (PRO140, HIS120). As for hydrogen bonds, the conformation was stabilized by the interaction of acetamide and heterocyclic carbonyl with the imidazole NH-group of histidine (His102). Location of the key

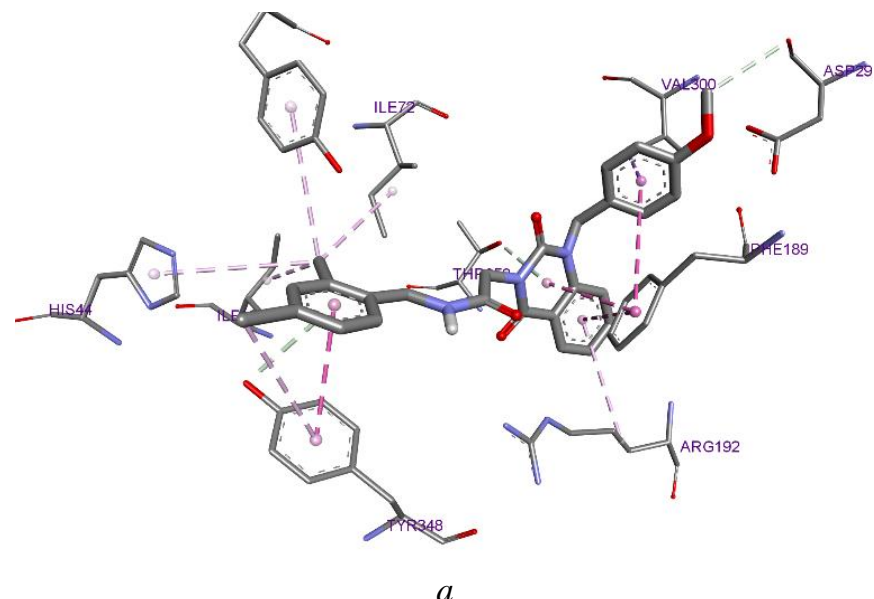

fragment of the modification - 1-benzyl radical - is rather doubtful because the interaction occurred with amino acids that did not form an active site in the experiment: tyrosine and serine (TYR68, SER205).

After a detailed analysis of the ligands 3.1-3.11 allocation in $\mathrm{GABA}_{\mathrm{AT}}$ active site, it should be noted that the hydrophobic interaction between the amino acids of the active site - valine (VAL300), phenylalanine (PHE189), arginine (Arg192) occurs only with quinazoline fragment of the ligand molecule (Fig. 7, $a, b$ ).

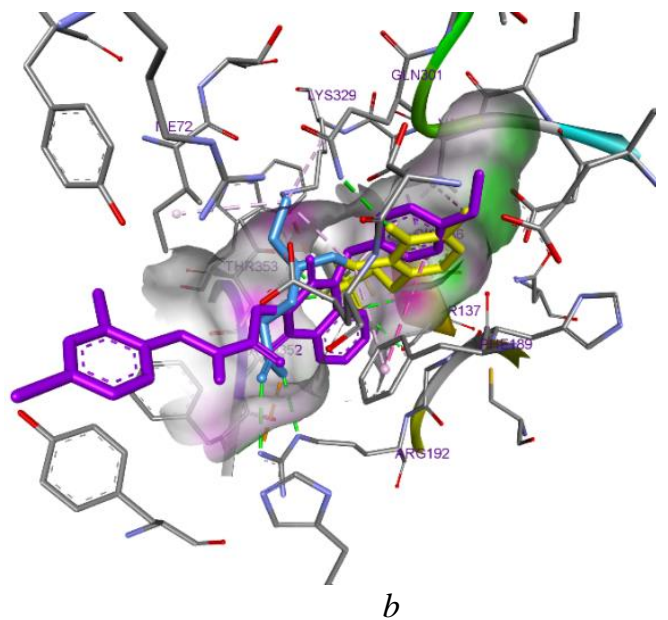

Fig. 7. 3D conformation in the active site of $\mathrm{GABA}_{\mathrm{AT}}$ : $a$ - ligand 3.9 with amino acids; $b$ - VGB (blue), ligand 3.9 (purple) and PLP (yellow)

At simultaneous allocation of VGN, pyridoxal-5phosphate (PLP) - GABA $\mathrm{AT}_{\mathrm{T}}$ co-factor and 3.9 ligand in the active site (Fig. $7, b$ ), it becomes obvious that the ligand molecule is too large and 2,4-dichlorobenzylamide fragment is not able to immerse into the hydrophobic pocket, so it allocates outside. Besides, 4-methoxybenzyl radical allocation occurs at cofactor fixation area and is being overlapped with PLP pyrimidine cycle. Therefore, according to the obtained molecular docking results, effect on GABAergic processes of ligands 3.1-3.11 due to $\mathrm{GABA}_{\mathrm{AT}}$ inhibition could be considered to be impossible.

Considering the ambiguous molecular docking parameters and the probability of affecting only the BZD site of $\mathrm{GABA}_{\mathrm{A}}$ receptor, only 5 of the 11 synthesized compounds, showing relatively better docking results, were selected for the further screening on the anticonvulsant activity in the PTZ-induced model. The obtained results are shown in Table 4.

The analysis of the results has shown that sodium valproate has a typical anticonvulsant effect, significantly reducing lethality from $100 \%$ to $50.0 \%(\mathrm{p}<0.01)$, the number of animals with clonic and tonic seizures - from $100 \%$ to 83 and $67 \%(\mathrm{p}<0.01)$, the severity of seizures in 1.43 times $(\mathrm{p}<0.05)$ and over than 6 times increasing the latency period of seizures $(\mathrm{p}<0.01)$.

Table 4

Anticonvulsant effect of N-[(2,4-dichlorophenyl)methyl]-2-(1-(R-benzyl)-2,4-dioxo-quinazolin-3-yl)acetamide (3) in the PTZ-induced seizures in mice $(\mathrm{M} \pm \mathrm{m})$

\begin{tabular}{|c|c|c|c|c|c|c|c|c|c|}
\hline \multirow[t]{2}{*}{$\begin{array}{l}\text { Group of } \\
\text { animals }\end{array}$} & \multirow[t]{2}{*}{ Dosemg $/ \mathrm{kg}$} & \multirow[t]{2}{*}{ Latency, min } & \multirow{2}{*}{$\begin{array}{l}\text { Number of } \\
\text { clonic-tonic } \\
\text { seizures in } \\
1 \text { mouse }\end{array}$} & \multicolumn{2}{|c|}{$\begin{array}{c}\% \text { of mice } \\
\text { with convul- } \\
\text { sions }\end{array}$} & \multirow{2}{*}{$\begin{array}{l}\text { Severity of } \\
\text { seizures, } \\
\text { points }\end{array}$} & \multirow{2}{*}{$\begin{array}{l}\text { Period of } \\
\text { seizures, } \\
\text { min }\end{array}$} & \multirow[t]{2}{*}{$\begin{array}{l}\text { Time to } \\
\text { death, min }\end{array}$} & \multirow[t]{2}{*}{$\begin{array}{c}\text { Lethality, } \\
\%\end{array}$} \\
\hline & & & & clonic & tonic & & & & \\
\hline Control & - & $3.92 \pm 0.38$ & $1.67 \pm 0.49$ & 100 & 100 & $6.00 \pm 0.00$ & $1.95 \pm 1.14$ & $5.87 \pm 1.01$ & 100 \\
\hline 3.2 & 100 & $4.34 \pm 1.72$ & $2.00 \pm 0.52$ & 100 & 100 & $5.67 \pm 0.33$ & $1.85 \pm 0.95$ & $7.88 \pm 0.93 *$ & 83 \\
\hline 3.5 & 100 & $3.76 \pm 1.19$ & $2.67 \pm 0.33$ & 100 & 100 & $6.00 \pm 0.00$ & $5.16 \pm 0.83$ & $8.92 \pm 1.22 *$ & 100 \\
\hline 3.9 & 100 & $5.67 \pm 0.92$ & $1.83 \pm 0.48$ & 100 & 100 & $5.67 \pm 0.33$ & $5.44 \pm 3.21$ & $8.87 \pm 2.87 *$ & 83 \\
\hline 3.10 & 100 & $4.65 \pm 1.16$ & $1.50 \pm 0.34$ & 100 & 100 & $6.00 \pm 0.00$ & $2.06 \pm 0.99$ & $6.71 \pm 0.87$ & 100 \\
\hline 3.11 & 100 & $3.77 \pm 1.12$ & $2.17 \pm 0.17$ & 100 & 100 & $5.67 \pm 0.33$ & $7.62 \pm 1.17 *$ & $9.49 \pm 1.21$ & 83 \\
\hline Valproate & 300 & $24.55 \pm 7.59 * *$ & $1.00 \pm 0.26$ & 83 & $67 * *$ & $4.17 \pm 0.98$ & $2.08 \pm 0.86$ & $19.32 \pm 2.20^{*}$ & $50 * *$ \\
\hline
\end{tabular}

Note: $n$-number of animals; $*-p<0.05$ when compared with control, $* *-p<0.01$ when compared with control

None of the studied compounds had a statistically significant anticonvulsant effect on the criterion of integral protective effect - reduction lethality against the control. Three compounds $(3.2,3.9,3.11)$ have shown a tendency to reduce lethality to $83 \%$ versus $100 \%$ in the control; they statistically significantly improved 1 indicator - lifetime of animals before death. Unfortunately, all the synthesized compounds were inactive comparing to 
PTZ-induced seizures and significantly inferior to sodium valproate.

\section{Discussion}

Conditions reproduction of the previous pharmacological experiment with the initial $\mathrm{N}-[(2,4-$ dichlorophenyl)methyl]-2-(1-(R-benzyl)-2,4-dioxoquinazolin-3-yl)acetamide (1) [Kayal] allows to compare results and discuss influence patterns of molecule fragments on anticonvulsant activity. The loss of anticonvulsant activity of N-[(2,4-dichlorophenyl)methyl]-2-(1-(Rbenzyl)-2,4-dioxo-quinazolin-3-yl)acetamide (1) is obvious when replacing 1 position of the quinazoline cycle with a benzyl radical for all protection indicators against PTZ-induced seizures. The obtained results of the study point to the inexpediency of such modification together with the key pharmacophore role of the cyclic amide fragment in activity manifestation of compound 1, acting as a hydrogen bond domain and probably stabilizing the ligand conformation in the active site of GABAergic biotargets by additional hydrogen bonds. In addition, the loss of activity may be associated with an increase in the compound's molecular weight, which should be $<500$ according to Lipinski's rule [35].

We could talk about a positive correlation between results of in vivo studies using the model of PTZinduced seizures and in silico studies, namely the values of binding energy and conformational allocation of ligands into the active sites of PAM benzamidine and diazepam in $\mathrm{GABA}_{\mathrm{A}}$ receptor and $\mathrm{GABA}_{\mathrm{AT}}$ enzyme. The obtained results substantiate the expediency of targetbased virtual screening for pharmacological screening rationalization in order to keep laboratory animals alive.

Study limitations. The use of other docking methodologies or other software to determine binding energy may vary. Therefore, validation of methodology depending on the native reference ligand should be performed every time.

Prospects for further research. According to the current guidelines and approaches for the search for new AEDs [36], despite the lack of results on the model of PTZinduced seizures for $\mathrm{N}$-[(2,4-dichlorophenyl)methyl]-2-(1-
(R-benzyl)-2,4-dioxo-quinazolin-3-yl)acetamide (3.1-3.11) their further study in using maximal electroshock model (MES), the model of psychomotor $6 \mathrm{~Hz}$ electricity stimulation and corneal kindled seizure seizures in mice, which characterizes chronic epilepsy, remains relevant.

\section{Conclusions}

As part of the pharmacophore model of antispasmodic activity implementation, a structural modification of the promising anticonvulsant $\mathrm{N}$-[(2,4-dichlorophenyl)methyl]2-(1-(R-benzyl)-2,4-dioxo-quinazolin-3-yl)acetamide was performed by implementation of substituted benzyl radicals. Selection of candidate structures for in vivo experiment was performed according to molecular docking into the active sites of $\mathrm{GABA}_{\mathrm{A}}$ receptor and $\mathrm{GABA}_{\mathrm{AT}}$ enzyme results in comparison with the native reference ligands - benzamidine, diazepam and vigabatrin. All the studied substances showed low affinity for the mentioned biotargets and were inferior to the reference drugs in terms of binding energy.

The low probability of GABAergic effect of the synthesized compounds in the in silico experiment was confirmed by the obtained results of pharmacological screening on PTZ-induced seizures in mice - the studied compounds did not show reliable activity, only 2 compounds showed a tendency to prevent lethality in the groups of animals. Dependence established between the conformational allocation of ligands in the active sites of the $\mathrm{GABA}_{\mathrm{A}}$ receptor and $\mathrm{GABA}_{\mathrm{AT}}$ and screening data, allows recommending the described docking methodology as a tool for rationalization and optimization of PTZinduced screening model. The pharmacophore role in anticonvulsant activity manifestation of the cyclic amide fragment of quinazoline cycle, as well as the positive effect of 4-methoxy group in the structure of aromatic fragments, was discussed.

\section{Conflicts of interest}

The authors declare that they have no conflicts of interest.

\section{Financing}

The study was performed without financial support.

\section{References}

1. Devinsky, O., Vezzani, A., O’Brien, T. J., Jette, N., Scheffer, I. E., de Curtis, M., Perucca, P. (2018). Epilepsy. Nature Reviews Disease Primers, 4 (1). doi: http://doi.org/10.1038/nrdp.2018.24

2. Janmohamed, M., Brodie, M. J., Kwan, P. (2020). Pharmacoresistance - Epidemiology, mechanisms, and impact on epilepsy treatment. Neuropharmacology, 168. doi: http://doi.org/10.1016/j.neuropharm.2019.107790

3. Löscher, W., Klein, P. (2021). The Pharmacology and Clinical Efficacy of Antiseizure Medications: From Bromide Salts to Cenobamate and Beyond. CNS Drugs, 35 (9), 935-963. doi: http://doi.org/10.1007/s40263-021-00827-8

4. Keezer, M. R., Sisodiya, S. M., Sander, J. W. (2016). Comorbidities of epilepsy: current concepts and future perspectives. The Lancet Neurology, 15 (1), 106-115. doi: http://doi.org/10.1016/s1474-4422(15)00225-2

5. Yuen, A. W. C., Keezer, M. R., Sander, J. W. (2018). Epilepsy is a neurological and a systemic disorder. Epilepsy \& Behavior, 78, 57-61. doi: http://doi.org/10.1016/j.yebeh.2017.10.010

6. Vossler, D. G., Weingarten, M., Gidal, B. E. (2018). Summary of Antiepileptic Drugs Available in the United States of America: working toward a world without epilepsy. Epilepsy Currents, 18 (4), 1-26. doi: http://doi.org/10.5698/1535-7597.18.4s1.1

7. Gaitatzis, A., Sander, J. W. (2013). The Long-Term Safety of Antiepileptic Drugs. CNS Drugs, 27 (6), 435-455. doi: http://doi.org/10.1007/s40263-013-0063-0

8. Chen, B., Choi, H., Hirsch, L. J., Katz, A., Legge, A., Buchsbaum, R., Detyniecki, K. (2017). Psychiatric and behavioral side effects of antiepileptic drugs in adults with epilepsy. Epilepsy \& Behavior, 76, 24-31. doi: http://doi.org/10.1016/j.yebeh.2017.08.039

9. Gesche, J., Christensen, J., Hjalgrim, H., Rubboli, G., Beier, C. P. (2020). Epidemiology and outcome of idiopathic generalized epilepsy in adults. European Journal of Neurology, 27 (4), 676-684. doi: http://doi.org/10.1111/ene.14142

10. Łukawski, K., Czuczwar, S. J. (2021). Understanding mechanisms of drug resistance in epilepsy and strategies for overcoming it. Expert Opinion on Drug Metabolism \& Toxicology, 17 (9), 1075-1090. doi: http://doi.org/10.1080/17425255.2021.1959912 
11. Khan, H. N., Kulsoom, S., Rashid, H. (2012). Ligand based pharmacophore model development for the identification of novel antiepileptic compound. Epilepsy Research, 98 (1), 62-71. doi: http://doi.org/10.1016/j.eplepsyres.2011.08.016

12. McCarthy, G., Myers, B., Siegfried, N. (2005). Treatment for Methaqualone dependence in adults. Cochrane Database of Systematic Reviews, 2. doi: http://doi.org/10.1002/14651858.cd004146.pub2

13. Ibrahim, M.-K., El-Adl, K., Al-Karmalawy, A. A. (2015). Design, synthesis, molecular docking and anticonvulsant evaluation of novel 6-iodo-2-phenyl-3-substituted-quinazolin-4(3H)-ones. Bulletin of Faculty of Pharmacy, Cairo University, 53 (2), 101-116. doi: http://doi.org/10.1016/j.bfopcu.2015.05.001

14. Abuelizz, H. A., Dib, R. E., Marzouk, M., Anouar, E.-H., A. Maklad, Y., N. Attia, H., Al-Salahi, R. (2017). Molecular Docking and Anticonvulsant Activity of Newly Synthesized Quinazoline Derivatives. Molecules, 22 (7), 1094. doi: http://doi.org/10.3390/ molecules22071094

15. El Kayal, W. M., Shtrygol, S. Y., Zalevskyi, S. V., Shark, A. abu, Tsyvunin, V. V., Kovalenko, S. M. et. al. (2019). Synthesis, in vivo and in silico anticonvulsant activity studies of new derivatives of 2-(2,4-dioxo-1,4-dihydroquinazolin-3(2H)yl)acetamide. European Journal of Medicinal Chemistry, 180, 134-142. doi: http://doi.org/10.1016/j.ejmech.2019.06.085

16. Jain, D., Singh, A., Patel, V., Veerasamy, R., Aggarwal, N., Rajak, H. (2017). Drug Design Strategies for the Discovery of Novel Anticonvulsants Concerned with Four Site Binding Pharmacophoric Model Studies. Central Nervous System Agents in Medicinal Chemistry, 17 (1), 30-50. doi: http://doi.org/10.2174/1871524916666160411143941

17. Tasso, S. M., Bruno-Blanch, L. E., Moon, S. C., Estiú, G. L. (2000). Pharmacophore searching and QSAR analysis in the design of anticonvulsant drugs. Journal of Molecular Structure: THEOCHEM, 504 (1-3), 229-240. doi: http://doi.org/10.1016/s01661280(00)00364-x

18. Severina, H. I., Skupa, O. O., Voloshchuk, N. I., Georgiyants, V. A. (2020). Synthesis, docking study, and pharmacological evaluation of S-acetamide derivatives of 4,6-dimethyl-2-thiopyrimidine as anticonvulsant agents. Journal of Applied Pharmaceutical Science, 10 (7), 1-8. doi: http://doi.org/10.7324/japs.2020.10701

19. Al-Salem, H. S. A., Hegazy, G. H., El-Taher, K. E. H., El-Messery, S. M., Al-Obaid, A. M., El-Subbagh, H. I. (2015). Synthesis, anticonvulsant activity and molecular modeling study of some new hydrazinecarbothioamide, benzenesulfonohydrazide, and phenacylacetohydrazide analogues of 4(3H)-quinazolinone. Bioorganic \& Medicinal Chemistry Letters, 25 (7), 1490-1499. doi: http://doi.org/10.1016/j.bmcl.2015.02.025

20. Zayed, M., Ihmaid, S., Ahmed, H., El-Adl, K., Asiri, A., Omar, A. (2017). Synthesis, Modelling, and Anticonvulsant Studies of New Quinazolines Showing Three Highly Active Compounds with Low Toxicity and High Affinity to the GABA-A Receptor. Molecules, 22 (2), 188. doi: http://doi.org/10.3390/molecules22020188

21. Matias, M., Campos, G., Silvestre, S., Falcão, A., Alves, G. (2017). Early preclinical evaluation of dihydropyrimidin(thi)ones as potential anticonvulsant drug candidates. European Journal of Pharmaceutical Sciences, 102, 264-274. doi: http://doi.org/10.1016/j.ejps.2017.03.014

22. Severina, H., Skupa, O., Khairulin, A., Voloshchuk, N., Georgiyants, V. (2019). Synthesis and anticonvulsant activity of 6-methyl-2-thioxo-2, 3-dihydropyrimidin-4(1H)-one acetamides. Journal of Applied Pharmaceutical Science, 9 (2), 12-19. doi: http://doi.org/10.7324/japs.2019.90202

23. Kehne, J. H., Klein, B. D., Raeissi, S., Sharma, S. (2017). The National Institute of Neurological Disorders and Stroke (NINDS) Epilepsy Therapy Screening Program (ETSP). Neurochemical Research, 42 (7), 1894-1903. doi: http://doi.org/10.1007/s11064-017-2275-z

24. Morris, G. M., Huey, R., Lindstrom, W., Sanner, M. F., Belew, R. K., Goodsell, D. S., Olson, A. J. (2009). AutoDock4 and AutoDockTools4: Automated docking with selective receptor flexibility. Journal of Computational Chemistry, 30 (16), 27852791. doi: http://doi.org/10.1002/jcc.21256

25. Protein Data Bank. Available at: http://www.rcsb.org/pdb/home/home.do Last accessed: 04.06.2021

26. Trott, O., Olson, A. J. (2009). AutoDock Vina: Improving the speed and accuracy of docking with a new scoring function, efficient optimization, and multithreading. Journal of Computational Chemistry, 31 (2), 455-461. doi: http://doi.org/10.1002/jcc.21334

27. Vogel, H. G.; Vogel, H. G. (Ed.) (2008). Chapter E: Psychotropic and neurotropic activity. Drug Discovery and Evaluation: Pharmacological Assays. Berlin: Springer-Verla, 565-876. doi: http://doi.org/10.1007/978-3-540-70995-4_6

28. Hock, F.J. (2016). Drug Discovery and Evaluation: Pharmacological Assays. Cham: Springer International Publishing, 4314. doi: http://doi.org/10.1007/978-3-319-05392-9

29. Severina, H., Skupa, O. O., Voloshchuk, N. I., Suleiman, M. M., Georgiyants, V. A. (2019). Synthesis and anticonvulsant activity of 6-methyl-2-((2-oxo-2-arylethyl)thio)pyrimidin-4(3 H)-one derivatives and products of their cyclization. Pharmacia, 66 (3), 141-146. doi: http://doi.org/10.3897/pharmacia.66.e38137

30. Miller, P. S., Aricescu, A. R. (2014). Crystal structure of a human GABAA receptor. Nature, 512 (7514), 270-275. doi: http://doi.org/10.1038/nature13293

31. Masiulis, S., Desai, R., Uchański, T., Serna Martin, I., Laverty, D., Karia, D. et. al. (2019). GABAA receptor signalling mechanisms revealed by structural pharmacology. Nature, 565 (7740), 454-459. doi: http://doi.org/10.1038/s41586-018-0832-5

32. Storici, P., Capitani, G., De Biase, D., Moser, M., John, R. A., Jansonius, J. N., Schirmer, T. (1999). Crystal Structure of GABAAminotransferase, a Target for Antiepileptic Drug Therapy. Biochemistry, 38 (27), 8628-8634. doi: http://doi.org/10.1021/bi990478j

33. Bialer, M., White, H. S. (2010). Key factors in the discovery and development of new antiepileptic drugs. Nature Reviews Drug Discovery, 9 (1), 68-82. doi: http://doi.org/10.1038/nrd2997

34. Egorova, E. V., Dmitrenko, D. V., Usoltseva, A. A., Iptyshev, A. M., Shnayder, N. A., Nasyrova, R. F. (2020). Modeling of chronic epilepsy in animals through chemical methods. Bulletin of Siberian Medicine, 18 (4), 185-196. doi: http://doi.org/10.20538/16820363-2019-4-185-196

35. Lipinski, C. A. (2016). Rule of five in 2015 and beyond: Target and ligand structural limitations, ligand chemistry structure and drug discovery project decisions. Advanced Drug Delivery Reviews, 101, 34-41. doi: http://doi.org/10.1016/j.addr.2016.04.029

36. Löscher, W. (2017). Animal Models of Seizures and Epilepsy: Past, Present, and Future Role for the Discovery of Antiseizure Drugs. Neurochemical Research, 42 (7), 1873-1888. doi: http://doi.org/10.1007/s11064-017-2222-z 
Wassim El Kayal, Postgraduate Student, Department of Pharmaceutical Chemistry National University of Pharmacy, Pushkinska str., 53, Kharkiv, Ukraine, 61002

Hanna Severina*, Doctor of Pharmaceutical Science, Associate Professor, Department of Pharmaceutical Chemistry, National University of Pharmacy, Pushkinska str., 53, Kharkiv, Ukraine, 61002

Vadim Tsyvunin, PhD, Assistant, Department of Pharmacology and Pharmacotherapy, National University of Pharmacy, Pushkinska str., 53, Kharkiv, Ukraine, 61002

Sergiy Zalevskyi, Postgraduate Student, Department of Pharmacology and Pharmacotherapy, National University of Pharmacy, Pushkinska str., 53, Kharkiv, Ukraine, 61002

Sergiy Shtrygol', Doctor of Medical Sciences, Professor, Department of Pharmacology and Pharmacotherapy, National University of Pharmacy, Pushkinska str., 53, Kharkiv, Ukraine, 61002

Sergiy Vlasov, Doctor of Pharmaceutical Sciences, Professor, Department of Pharmaceutical Chemistry, National University of Pharmacy, Pushkinska str., 53, Kharkiv, Ukraine, 61002

Olga Golovchenko, PhD, Associate Professor, Department of Pharmaceutical Chemistry, National University of Pharmacy, Pushkinska str., 53, Kharkiv, Ukraine, 61002

Sergiy Kovalenko, Doctor of Chemical Sciences, Professor, Department of Organic Chemistry, Karazin Kharkiv National University, Svobody sq., 4, Kharkiv, Ukraine, 61022

Victoriya Georgiyants, Doctor of Pharmaceutical Sciences, Professor, Head of Department, Department of Pharmaceutical Chemistry, National University of Pharmacy, Pushkinska str., 53, Kharkiv, Ukraine, 61002

*Corresponding author: Hanna Severina, e-mail: severina.ai@ukr.net 